Silveira-Junior, W.J.; Botelho, E.S. Turismo em áreas protegidas e inclusão social de populações tradicionais: um estudo de caso da Cooperativa de Ecoturismo de Guaraqueçaba (PR). Anais do VIII Congresso Nacional de Ecoturismo e do IV Encontro Interdisciplinar de Ecoturismo em Unidades de Conservação. Revista Brasileira de Ecoturismo, São Paulo, v.4, n.4, 2011, p. 525.

\title{
TURISMO EM ÁREAS PROTEGIDAS E INCLUSÃO SOCIAL DE POPULAÇÕES TRADICIONAIS: UM ESTUDO DE CASO DA COOPERATIVA DE ECOTURISMO DE GUARAQUEÇABA (PR)
}

\author{
Wanderley Jorge Silveira-Junior*, Eloise Silveira Botelho** \\ *ONG Grupo Brasil Verde, **Universidade Federal de Juiz de Fora \\ E-mails: jjjuniorjf@hotmail.com, eloisebotelho@hotmail.com
}

s populações tradicionais estabelecidas no entorno ou no interior de áreas protegidas têm buscado alternativas que compatibilizem a subsistência com a conservação ambiental e valorização cultural. Nesse processo, o turismo tem sido elencado como a alternativa capaz de compatibilizar esses interesses. O tema central desse artigo perpassa o debate sobre o turismo em áreas protegidas, e as possibilidades e limites de inclusão social das populações tradicionais. Nesse contexto, a iniciativa da Cooperativa de Turismo de Guaraqueçaba (Cooperguará-ecotur), Paraná, é um interessante estudo de caso que traz uma série de questões que precisam ser conhecidas e debatidas no âmbito acadêmico. Assim, esse artigo tem por objetivo analisar a iniciativa de turismo adotada pelos caiçaras membros da Cooperguaráecotur e refletir sobre as possibilidades e limites do turismo de base comunitária em áreas protegidas. Como resultado da pesquisa qualitativa, que envolveu entrevistas e observação direta in loco, identificou-se que o turismo de base comunitária, protagonizado pelos caiçaras a partir da criação de uma cooperativa, tem possibilitado a perspectiva de inclusão social. Tal iniciativa tem contribuído para a organização social local, bem como para a capacitação e fomento do turismo. A iniciativa colaborou para que a economia local se diversificasse, valorizando cultura local e permitindo que os caiçaras permaneçam em seus territórios. O estudo de caso aponta também algumas fragilidades que podem dificultar o desenvolvimento do turismo local, incitando o debate acadêmico sobre o tema.

Palavras-chave: Turismo; Populações Tradicionais; Áreas Protegidas; Inclusão Social. 